\title{
THE CAUSES OF CULLING IN BOHEMIAN PIBD CATTLE AND CROSSBS WITH THE RED HOLSTEIN AND AYRSHIRE BREEDS
}

\section{P. BRAUNER}

Department of Prevention of Pig Diseases, Animal Breeding Husbandry and Zoohygiene, University of Veterinary Science, 61242 Brno

Received March 27, 1987

\begin{abstract}
B $r$ a $u$ e $r$ P.: The Causes of Culling in Bohemian Pied Cattle and Crosses with the Red Holstein and Ayrshire Breeds. Acta.vet.Brno, 56,1987:65-72.

In the present study, complete culling was investigated up to the 3rd lactation. The lowest percentage of culling was found in the CR crosses (Bohemian Pled X Red Holstein), in the CA (Bohemian Pied $X$ Ayrshire) crosses it was slightly higher, while the percentage of culling was the highest in group C (Bohemian Pled cattle). That culling was markedly lower in the $C R$ and $C A$ crosses than in group $C$ could be due to the heterose effect in the crosses.

In the individual breeding groups the dairy cows with the lowest efficiency were culled according to the sequence of lactation; the percentage of culling was the highest in dairy cows on the 3rd lactation, the percentage of $C R$ crosses being lower (1.e. 53.57\%) than of the CA crosses (1.e. 60.00\%) and group C (1.e. 57.89\%). Culling in the 3rd lactation due to disorders in reproduction was much lower, the lowest percentage being that of CR crosses (1.e. 3.57\%). On the contrary, the highest percentage of culling in the 3rd lactation was found to be among the CR crosses and was due to diseases, functional disorders and morphological changes of the mammary gland (1.e. 25\%). In the CR crosses the highest percentage of culling due to diseases of the locomotor organs cccurred in the 2nd lactation (1.e. 33.33\%) at the time when the cows were trasferred to a cow shed with short stanchions and grated dunging pits.
\end{abstract}

Culling, Bohemian Pied cattle, crosses of the Bohemian Pied with the Red Holstein and Ayrshire cattle

In 1971, improvement crossing of the domestic cattle with the Red Holstein cattle of American-Canadian origin was begun in Czechoslovakia. The reason for selecting the Red Holstein breed was its high milk efficiency acquired abroad.

The aim of the present study was to carry out an evaluation of the commercially important indices of efficiency of the dairy cows and the degree and reasons for culling of crosses of Bohemian Pled cattle with Red 
Holstein and Ayrshire breeds. Comparisons were then to be carrled out with the Bohemian Pled cattle under conditions of the School Agricultural Enterprise of the University of Veterinary Science in Nový Jičin.

Studies of the reasons for culling are important from the aspect of health, production and rentability of the herd.

As concerns the complete culling of dams in the herd, $S$ u $c h$ á $n$ et al. (1972) found that culling of CA crosses during the 1st to 3rd lactation was by 2.3 - 37.37 lower as compared with the $C$ group. $S u c h$ á $n$ e $k$ and U 1 r y c h (1975) found that the percentage of culling in the Bohemian Pled $X$ Ayrshire crosses in the lst lactation was by 5.2 - $15.8 \%$ lower than in group C. According to $S$ u $c h$ á $n$ e $k$ and $U 1$ y $c h$ (1976) the degree of culling of CA crosses from the original number of cows was half of that of the herd mates of group C. U 1 r y $c h$ and $S u c h$ á $n k$ (1977) report that culling in CA crosses was by $10 \%$ lower as compared with group C. S u$c h$ á $n$ e $k$ et al. (1980) investigated culling in CA crosses and found that it was by $4.4-21.8 \%$ lower than in the group $C$ herd mates. S $\mathrm{c} h$ á$n e k$ and G $\circ 1 \mathrm{~d}$ a (1983) found that the total degree of culling of $C R$ crosses was by 5.5 - $16.7 \%$ lower as compared with dams of group $C$. $S u c h$ án e $k$ (1982) reported that the degree of culling in CR crosses was by $8.5 \%$ lower than in the herd mates of group C. J u r č o (1985) observed a high percentage of culling, 1.e. $38 \%$, and in large-scale technologies even $41 \%$. He confirmed tha fact that high-efficiency dairy cows are culled especially due to disorders in fertility, diseases of the locomotor organs and diseases of the mammary gland. In the German Democratic Republic, K 1 r $8 t$ (1979) investigated the culling of cows in large-scale cow houses. The most frequent reason was selection according to efficiency, disorders in reproduction and diseases of the udder (1.e. $11.9,10.2$ and $7.1 \%$, respectively). In Holland, $R$ e $\mathrm{n} \mathrm{e} \mathrm{m} \mathrm{a} \mathrm{and} S \mathrm{t} e \mathrm{w}$ a $\mathrm{g}$ e $\mathrm{n}$ (1979) studied the reasons of culling In the Dutch Friesian cattle where disorders in reproduction, diseases of the udder and low efficiency were 25, 20 and 15\%, respectively. $\mathrm{S} 1 \mathrm{p} \mathrm{k}$ and $H$ a $\mathrm{J} \perp \mathrm{C} \quad$ (1981) evaluated culling in the Bohemian Pled breed in the 2nd and following lactations. Due to low efficiency, unfertility and diseases of the udder, $33.54,27.34$ and $8.45 \%$ of the total number of cows were culled, respectively. $S$ u $c h a ́ n e k$ and $B \circ z \circ v s k \dot{y}$ (1982) found that the degree of culling of CA crosses due to zootechnical reasons and/or due to low efficiency was low; the degree of culling due to zootechnical reasons and/or low efficiency was the highest in dairy cows of group C. W o $1 \mathrm{f}$ (1982) reported that in the GDR the reasons for culling were low efficiency (38.7\%), disorders in fertility (15.5\%) and diseases of the udder (12.5\%). V á c h a 1 (1983) stated that the percentage of culling of the CR crosses in the lst. lactation due to various disorders of health was $7.6-11.7 \%$, that in increased with the sequence of lactations and that it reached $14.6-19.1 \%$ in the $3 \mathrm{rd}$ lactation. L o $t \mathrm{t} \mathrm{h}$ a m m e $r$ (1984) studied the culling of cows in the period from 1978 to 1982 and he found that 29.3 to $30.9 \%$ of cows were culled due to disorders in fertility. According to $\mathrm{K}$ a $\mathrm{d}$ e č $\mathrm{k}$ a (1985) the basis for good reproduction is such a situation when culling due to disorders in reproduction is not higher than $10 \%$. He reported that more than $25 \%$ of dairy cows are now being culled due to disorders of fertility. $K$ á 1 et al. (1977) reported that 10, 20\% or even more of the culling is due to diseases of the locomotive organs. G $r$ e $n \circ u g h$ et al. (1981) found that diseases of the limbs in cattle are on the $3 \mathrm{rd}$ and $4 \mathrm{th}$ place in causes of culling of dairy cows. The percentage of culling due to this disorder has reached as much as $40 \%$ in New Zealand, $1.5 \%$ in Great Britain, $3 \%$ in the FRG and in some countries as much as $13.9 \%$. W o $1 \mathrm{f}$ (1982) reported that the percentage of culling due to disorders of the locomotor organs of dairy cows 


\section{Materials and Methods}

The present task was carried out as a comparative experiment with three groups of dams: Bohemian Pied cattle (C) $n=46$, Bohemian Pied $X$ Red Holstein crosses with a 508 proportion of blood (CR) $n=62$ and Bohemian Pied $X$ Ayrshire cattle with a blood proportion ranging from 25 to $53.25 \%$ (CA) $n=$ 65. In order to ensure identic environmental conditions, these breeding, groups were concentrated on one farm. The high-pregnant heifers were housed in the barn for primiparae and in the 2 nd and 3 rd lactations they were transferred to a large-scale cow-shed with short stanchions and grated dunging

pit. Investigations were carried out under normal conditions of management of the School Agricultural Enterprise of the University of Veterinary Science in Nový Jixin; this enterprise had been selected for tests of the genetic pool of foreign breeds of dairy cows to be crossed with the Bohemian Pied cattle.

An overall survey of culling and its causes were continuously followed from veterinary documentation, primary zootechnical records and entries of the performance control separately for the first, second and third lactation. The differences of the individual breeding groups were calculated from these data and expressed in per cent.

\section{Results}

Tab. 1 gives the number of culled animals within the breeding. groups compared in the individual time periods since birth till the 3rd lactation. It can be seen that in the lst lactation 37.008 of cows included in the experiment in group $C$ were culled; in the $C A$ and $C R$ crosses the percentage was by 10.58 and 22.958 lower, respectively, than in group $C$. In the 2 nd lactation it was 11.008 in group $C$; in $C R$ and $C A$ crosses it was by 1.08 and $3.45 \%$ lower, respectively, than in group C. In the 3rd lactation it was 19.008 of dairy cows; in the CA and CR crosses it was by 4.14 and 4.588 higher.

Tab. 2 gives the causes of culling within the individual breeding groups according to the sequence of lactations. The division of causes of culling of the experimental dairy cows given in per cent shows the differences among the groups in the individual lactations. In the lst lactation, the highest percentage of culling due to low efficiency was found in the CR crosses (i.e. $41.18 \%$ ), in the 2nd lactation the percentage of culled cows was the highest in group $C$ (i.e. 27.27\%) and in the 3rd lactation in the CA crosses (i.e. 60.008). In the lst lactation culling due to disorders in reproduction was the highest in the CR crosses (i.e. 35.298), in the 2nd lactation in the $C R$ and $C A$ crosses (i.e. 50.00\%) and in the 3rd lactation in the CA crosses (i.e. 20.008). Diseases, functional disorders and morphological changes of the milk gland were the causes of culling of the CR crosses in the lst lactation and the 3 rd lactation (i.e. 17.65 and 25.008 , respectively). In the 2nd lactation, 18.188 of dams were culled in group $C$ due to the same causes. As compared with the other groups, the post-parturition complications as a cause of culling were the lowest in $C R$ crosses in all lactations. More post-parturition complications occurred in the 2nd lactation in dams of group C (i.e. 27.27\%) and in the CA crosses (i.e. 25.00\%). Other disorders of the sexual organs were recorded in the lst lactation only in groups $\mathrm{C}$ and CA. The occurrence of diseases of the locomotor organs was marked in the $2 \mathrm{nd}$ lactation in CR crosses (i.e. 33.33\%) while in the 3rd lactation it was only 
Table 1

Total culling of the investigated breeding groups from birth till the 3rd lactation

\begin{tabular}{|c|c|c|}
\hline CR group & $n=120$ & \\
\hline $\begin{array}{l}\text { up to } 6 \text { months of age } \\
\text { up to } 21 \text { months of age } \\
\text { up to the lst lactation } \\
\text { up to the 2nd lactation } \\
\text { up to the 3rd lactation } \\
\text { living }\end{array}$ & $\begin{array}{l}20 \text { head } \\
14 \text { head } \\
17 \text { head } \\
12 \text { head } \\
28 \text { head } \\
30 \text { head }\end{array}$ & $\begin{array}{r}16.53 \% \\
11.57 \% \\
14.05 \% \\
9.92 \% \\
23.14 \% \\
24.79 \%\end{array}$ \\
\hline C group & $n=100$ & \\
\hline $\begin{array}{l}\text { up to } 6 \text { months of age } \\
\text { up to } 21 \text { months of age } \\
\text { up to the lst lactation } \\
\text { up to the 2nd lactation } \\
\text { up to the } 3 \text { rd lactation } \\
\text { living }\end{array}$ & $\begin{array}{r}16 \text { head } \\
4 \text { head } \\
37 \text { head } \\
11 \text { head } \\
19 \text { head } \\
13 \text { head }\end{array}$ & $\begin{array}{r}16.00 \% \\
4.00 \% \\
37.00 \% \\
11.00 \% \\
19.00 \% \\
13.00 \%\end{array}$ \\
\hline CA group & $\mathrm{n}=106$ & \\
\hline $\begin{array}{l}\text { up to } 6 \text { months of age } \\
\text { up to } 21 \text { months of age } \\
\text { up to the lst lactation } \\
\text { up to the 2nd lactation } \\
\text { up to the 3rd lactation } \\
\text { living }\end{array}$ & $\begin{aligned} 6 & \text { head } \\
14 & \text { head } \\
28 & \text { head } \\
8 & \text { head } \\
25 & \text { head } \\
25 & \text { head }\end{aligned}$ & $\begin{array}{r}5.66 \% \\
13.21 \% \\
26.42 \% \\
7.55 \% \\
23.58 \% \\
23.58 \%\end{array}$ \\
\hline
\end{tabular}

3.57\%. Due to orthopedic disorders, 10.53 and 8.008 of cows of group $C$ and CA crosses, respectively, were culled in the 3 rd lactation. Attention should be paid to the highest percentage of culling (i.e. 14.2\%) due to traumatic diseases of the digestive system in the $3 r d$ lactation in the CR crosses. The percentage of culling due to acute diseases and emergency slaughter was the highest (i.e. 8.118) in the lst lactation in group C.

\section{Discussion}

The total percentage of culling in the groups investigated in the present study in the lst and 2nd lactations corresponds with the results of $\mathrm{S} u$ c há ne k et al. (1972), S u c há $n e k$ and U l r y c h (1975), S u c há $n e k$ and $G o .1 d a$ (1983) and $S$ u c há n e k (1982). Contrary to the data given by the above authors, in our present study culling was by 4.14 and 4.588 higher in the CA and CR crosses, respectively, in the 3rd lactation than in group $C$.

Culling due to low efficiency as given by various authors reached 158 ( R e $\mathrm{n} \mathrm{k} \mathrm{e} \mathrm{m} \mathrm{a} \mathrm{and} \mathrm{St}$ e $l$ w a $\mathrm{g}$ e $\mathrm{n} \mathrm{1979),} \mathrm{11.98} \mathrm{(K} \mathrm{i} \mathrm{r} \mathrm{s} \mathrm{t} \mathrm{1979),}$ 33.548 ( $\mathrm{S} \mathrm{l} \mathrm{i} \mathrm{p} \mathrm{k}$ and $\mathrm{H} \mathrm{a} \mathrm{j} \mathrm{i} \mathrm{c} \mathrm{1981),} \mathrm{38.7 \%} \mathrm{(W} \mathrm{o} \mathrm{l} \mathrm{f} \mathrm{1982).}$ According to $\mathrm{V}$ á c h a 1 (1983) culling in the CR crosses was by 2.8 to 13.28 lower in the $C R$ crosses than in their herd mates of group $C$. In our present observations we found that the percentage of culling was the lowest 
Table 2

Causes of culling within the individual breeding groups according to the sequence of lactations in per cent

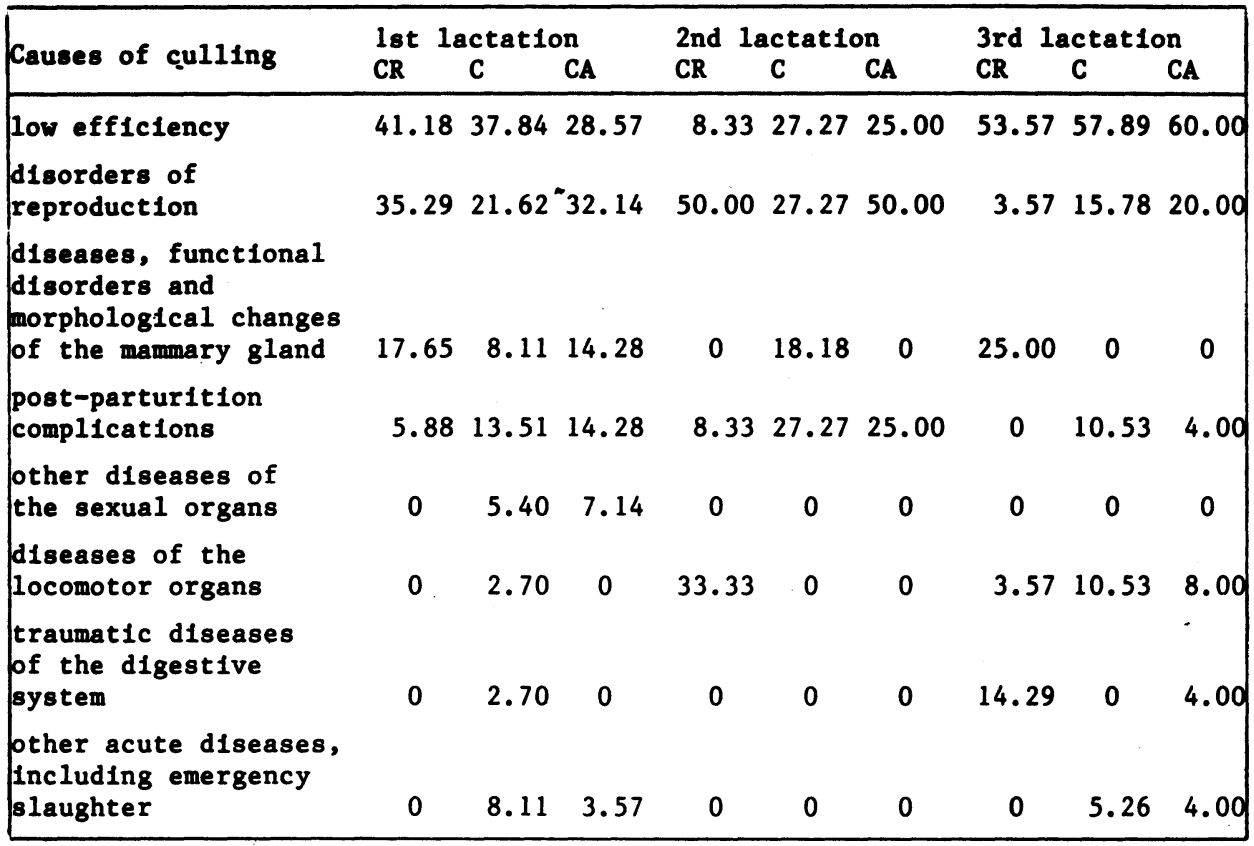

in the 1st lactation in the $C R$ crosses; there was a marked decrease in the $C R$ crosses in the 2 nd lactation. The percentage of culling was nearly the same in group $C$ and the CA crosses. Very interesting is the finding that more than 50.008 of all the groups investigated were culled in the 3rd lactation due to low efficiency. The percentage of culling of our crosses is in accordance with data given by other authors only as concerns the differences between the lst and the 2 nd lactation. While other authors reported that with continuing lactations the percentage of culling in the crosses continuously decreased, in our breeding groups the percentage of culling was found to be the highest in the 3rd lactation.

Many authors dealt with problems connected with culling due to disorders in reproduction. The values given were 10.28 ( $\mathrm{K}$ i r s t 1979),

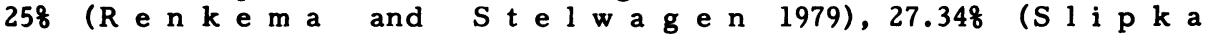

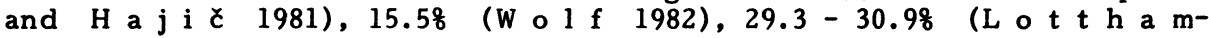
$\mathrm{m}$ e $\mathrm{r}$ 1984) and 258 ( $\mathrm{K}$ a $\mathrm{d}$ e č $\mathrm{k}$ a 1985). According to $\mathrm{V}$ á $\mathrm{c} h \mathrm{~h} \mathrm{l}$ (1983), the percentage of culling of the CR crosses in the lst lactation due to health disorders reached 7.6. - 11.7\%. The percentage found in the present study in all the three breeding groups was nearly twice as high as the data of V a c h a 1 (1983). In the 2nd lactation, culling of the CR and CA crosses considerably increased due to disorders in reproduction, only the

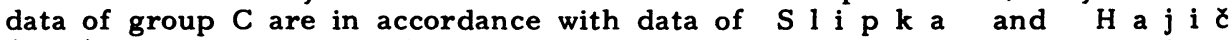
(1981). The percentage of culling in the 3 rd lactation in the CR crosses due 
to disorders in reproduction was relatively low, i.e. 3.57\%. The lower percentage of culling in the 3rd lactation in all the groups compared can be explained by a stricter selection for reproduction reasons in the lst and especially in the 2nd lactation.

Due to disorders of the milk gland, $R$ e $\mathrm{n} k \mathrm{e} \mathrm{m} \mathrm{a} \mathrm{and} S \mathrm{t} e$ 1-

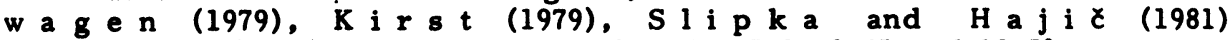
and $W \circ 1 \mathrm{f}$ (1982) give the values of $20.00,7.1,8.45$ and 12.58 , respectively. The percentage of culling due to disorders of the milk gland in the groups investigated is practically in accordance with data of these authors, only in the CR crosses in the 3rd lactation the percentage of culling was found to be the highest, i.e. 25.008, what can be explained by a higher reaction and sensitivity of the $C R$ crosses to the conditions of breeding and by their higher milk production.

Post-parturition complications were the lowest in the CR crosses in all the three lactations, whereas culling was the highest in group $C$ and in the CR crosses in the 2nd lactation.

According to $\mathrm{K} \mathbf{r}$ á $\mathbf{l}$ et al. (1977), G r e e $\mathrm{n} \circ \mathbf{u} \mathbf{g ~ h}$ et al. (1981) and $W \circ 1 \mathrm{f}$ (1982), culling due to disorders of the locomotor organs reached 10 - 20 or more, $1.5-40$ and $4.3 \%$, respectively. The percentage of culling in the groups investigated in the present study are virtually the same as data of these authors, only in the 2 nd lactation this percentage increased to 33.338 in the CR crosses what can be explained by their higher sensitivity and bigger body framework as compared with the CA crosses and dams of group $C$ and due to the transfer of dairy cows on the 2 nd lactation to the large-scale cow-shed with short stanchions and grated dunging pit. This high percentage of culling in the 2 nd lactation was very favourably reflected in the 3rd lactation when culling due to orthopedic disorders in the CR crosses decreased to 3.578 .

On the basis of analysis of the causes of culling it is necessary to carry out the required measures in nutrition, in the field of prevention, management and zoohygiene.

Přłčiny vyřazování českého strakatého skotu a křx̌̌enek s červeným holštýnským a ayrshirským plemenem

V rámci cęlkového vyřazování sledovaných plemenných skupin do III. laktace bylo nejnižśi procento vyřazování zjištěno u křiženek CR (Českého strakatého s Červeným holštýnským), poněkud větší u křiženek CA (Českého strakatého s ayrshirským), zatímco nejvyššího vyřazování dosáhla skupina C (Český strakatý skot). U obou skupin křiženek $C R$ a CA bylo vyřazování podstatně nižši ve srovnání s plemenicemi $C$, což lze přičist heteróznímu efektu u křiženek.

Z přícin vyřazování dojnic jednotlivých plemenných skupin dle pořadí laktace bylo pro nízkou užitkovost vyřazeno nejvíce dojnic $v$ rámci všech plemenných skupin na III. laktaci, přičemž křiženky CR $(53,578)$ měly toto vyřazování nižší než kříženky CA $(60,008)$ a skupina C $(57,898)$. Pro poruchy reprodukce bylo na III. laktaci vyřazení podstatně menší, z toho opět křiženky CR měly vyřazení nejnižší $(3,578)$. Naopak kř́ženky CR dosáhly nejvyšŠího vyřazování na III. laktaci z důvodů onemocnění, funkčních poruch a morfologických změn mléčné žlázy $(25,008)$. U kř́ženek $C R$ bylo nejvyšší procento vyřazení pro onemocnění pohybového aparátu zaznamenáno na II. laktaci $(33,33 \%)$, kdy byly převedeny do stáje s, krátkým stáním se zaroštovaným kalištěm. 
Причины выбраховки чешской пестрой породы и помесей с храсной гольштейской и айтирской породами

В рамхах обшей выбраховки исследуемых племенных групп до m лахтации самый низхй процент выбраховки был установлен у помесей CR (чешская пестрая с храсной гольштейнской породой), несколько больше у помесей CA (чешская пестрая порода $\mathrm{C}$ айтирской породои), уежду тем ках самая большая выбраховка встречалась у группы C (чешская пестрая порода). У обеих групп помецей CR и CA выбраховка была существенно ниже по сравнению с племенными матхами $C$, что можно связать с гетерозным еффектом помесай.

из причин выбраховки дойных коров отдельных племенных групп по порядху лахтации из-за низкой продухтивности было самое большое количество дойых хоров в рамхах всех племенных групп отбраковано на стадии II лахтации, при этом помесь CR $(53,578)$ отличалась по сравнению с помесью СА $(60,008)$ и группой C $(57,898)$ меньшей выбраховкой. Из-за нарушений репродухции на стадии 巴 лахтации выбраковка была существенно ниже, у помесей CR была опят-тахи самая низкая $(3,578)$. Наоборот, помесь CR достигла самой высохой выбраховки во время Ш лахтации по причинам заболевания, фунхциональных нарушений и морфологических измененй молочной железы $(25,008)$. У помесей $\mathrm{CR}$ причина самого большого процента выбраховки сводилась $x$ заболеваниям двигательного аппарата на П лактации $(33,338)$, хогда коровы были переведены в коровних с коротким стойлом и решеткой похрытым отводным каналом.

\section{References}

GRenNoUgh, P.R. - Mac CATLEM, F.J. - WEAWER, A.D.: Lameness in cattle. Wright, Scientechnica 1981: 471 .

JURC̄o, V.: Význam predIženia produkčného veku dojníc, Náš Chov, 1985: 492494.

KADECKA, J.: Základy dobré reprodukce krav. Zeměd. Nov. Zemědělec, 9.10.1985.

KIRST, E.: Zu einigen Aspekten der Reproduktion in industriemässing produzierenden Milchviehanlagen. Tierzucht, 33, 1979: 224-226.

KRAL, E. - HOJOVEC, J. - KUBIČE, A. - LABIK, K. : Péče o paznehty v nových formách ustájeni skotu. SZN, Praha, 1977: 90.

LOTTHAMMER, K.: Bonn, Auswertungs- und Informations- lents für Ernährung, Landwirtschaft und Forsten, 1984: 24.

RENKEMA, J.A. - STELWAGEN, J.: Economic evaluation of replacement rates in dairy herds. Livestock Production Science, 1979: 15-27.

SLIPKA, J. - HAJIČ, F.: Příčiny vyřazování dojnic ve výše položených oblastech. In: Sbor. Prov. ekon. Fak. C. Budějovice, 1981: 127-139.

SUCHANEK, B. - ULRYCH, A. - PILÃT, Z. - et al.: Mléčná užitkovost křiženek českého strakatého plemene s ayrshirským. Živoč. Výr., 17, 1972: 147-156.

SUCHANEK, B. - ULRYCH, A.: Zušlechťovací kříženi českého strakatého plemene s ayrshirským. Rapotín, Project report, 1975: 65.

SUCHANER, B. - ULRYCH, A.: Stupeñ a příčiny vyřazování křiženek českého strakatého plemene s ayrshirským. Živož. Výr., 21, 1976: 727-733.

SUCHANEK, B. - ULRYCH, A. - BOŽOVSKY, A.: Užitkovost křiženek ve velkokapacitnich kravínech, Project report, Rapotín, VOCHS, 1980. 37 
SUCHANEK, B.: Vytváření typů skotu ve velkokapacitnich kravínech. Výzk. Chovu Skotu, 24, 1982: 18-24.

SUCHANEK, B. - BOŽOVSKY, A.: Mléčná užitkovost a vyřazování krav různých užitkových typů ve velkokapacitních kravinech. Żivoč. Výr., 27, 1982: 493-501.

SUCHANEK, B. - GOLDA, J.: Už1tkovost křiženek Českého strakatého skotu s Cerveným holštýnským skotem. Žlvoč. Výr., 28, 1983: 161-167.

ULRYCH, A. - SUCHANEK, B.: Už1tkové vlastnosti křiženek druhé fillální generace českého strakatého skotu s ayrshirským plemenem. Výzk. Chovu Skotu, 19. 1977: 13-17.

VÁCHAL, J.: Realizace komplexního programu šlechtěni českého strakatého skotu. Project report, Uhřiněves, vơ̌zv, 1983: 75.

WOLF, J.: Abgangsursachen. in industriemässigen Milchproduktionsanlagen und thre Beziehung zur Fruchtbarkeit. Tierzucht, 36, 1982: 220-222. 